\title{
Evaluation of Plant and Fungal Extracts for Their Potential Antigingivitis and Anticaries Activity
}

\author{
D. A. Spratt, ${ }^{1}$ M. Daglia, ${ }^{2}$ A. Papetti, ${ }^{2}$ M. Stauder, ${ }^{3}$ D. O'Donnell, ${ }^{1}$ L. Ciric, ${ }^{1}$ A. Tymon, ${ }^{1}$ \\ B. Repetto, ${ }^{3}$ C. Signoretto, ${ }^{4}$ Y. Houri-Haddad, ${ }^{5}$ M. Feldman, ${ }^{6}$ D. Steinberg, ${ }^{6}$ S. Lawton, ${ }^{1}$ \\ P. Lingström, ${ }^{7}$ J. Pratten, ${ }^{1}$ E. Zaura, ${ }^{8}$ G. Gazzani, ${ }^{2}$ C. Pruzzo, ${ }^{3}$ and M. Wilson ${ }^{1}$ \\ ${ }^{1}$ Department of Microbial Diseases, UCL Eastman Dental Institute, 256 Gray's Inn Road, London WC1X 8LD, UK \\ ${ }^{2}$ Department of Drug Sciences, School of Pharmacy, University of Pavia, Via Taramelli 12, 27100 Pavia, Italy \\ ${ }^{3}$ DIPTERIS, University of Genoa, Corso Europa 26, 16132 Genoa, Italy \\ ${ }^{4}$ Dipartimento di Patologia-Sezione di Microbiologia, Università di Verona, 37134 Verona, Italy \\ ${ }^{5}$ Department of Prosthodontics, Faculty of Dental Medicine, Hebrew University-Hadassah, 91120 Jerusalem, Israel \\ ${ }^{6}$ Biofilm Research Laboratory, Faculty of Dental Medicine, Hebrew University-Hadassah, 91120 Jerusalem, Israel \\ ${ }^{7}$ Department of Cariology, Institute of Odontology, The Sahlgrenska Academy, University of Gothenburg, 40530 Gothenburg, Sweden \\ ${ }^{8}$ Department of Preventive Dentistry, Academic Centre for Dentistry Amsterdam (ACTA), University of Amsterdam and Free University \\ Amsterdam, Gustav Mahlerlaan 3004, 1081 LA Amsterdam, The Netherlands
}

Correspondence should be addressed to D. A. Spratt, d.spratt@ucl.ac.uk

Received 9 August 2011; Revised 7 November 2011; Accepted 10 November 2011

Academic Editor: Itzhak Ofek

Copyright () 2012 D. A. Spratt et al. This is an open access article distributed under the Creative Commons Attribution License, which permits unrestricted use, distribution, and reproduction in any medium, provided the original work is properly cited.

\begin{abstract}
The link between diet and health has lead to the promotion of functional foods which can enhance health. In this study, the oral health benefits of a number of food homogenates and high molecular mass and low molecular mass fractions were investigated. A comprehensive range of assays were performed to assess the action of these foods on the development of gingivitis and caries using bacterial species associated with these diseases. Both antigingivitis and anticaries effects were investigated by assays examining the prevention of biofilm formation and coaggregation, disruption of preexisting biofilms, and the foods' antibacterial effects. Assays investigating interactions with gingival epithelial cells and cytokine production were carried out to assess the foods' anti- gingivitis properties. Anti-caries properties such as interactions with hydroxyapatite, disruption of signal transduction, and the inhibition of acid production were investigated. The mushroom and chicory homogenates and low molecular mass fractions show promise as anti-caries and anti-gingivitis agents, and further testing and clinical trials will need to be performed to evaluate their true effectiveness in humans.
\end{abstract}

\section{Introduction}

During the last decade epidemiological studies have demonstrated a clear relationship between diet and health and this has resulted in new roles being ascribed to foods. Foods are now not only regarded as being an indispensable source of nutriment but are also considered to be beneficial in many ways. Foods that have some particular beneficial effects on health are generally defined as functional foods $[1,2]$. Their activity is determined by a specific and selective interaction of their minor components with one or more physiological functions of the organism. Both simple foods and food products, meaning technologically treated foods in which their chemical composition and, therefore, their organoleptic, nutritional, or biological characteristics have been changed, are considered functional foods. Foods depleted in, or enriched with, specific components can also be considered to be functional foods.

Caries is one of the most prevalent chronic diseases of humans. It is an endogenous infection of the calcified tissues of the teeth and is a result of their demineralisation by organic acids produced by those plaque bacteria that ferment dietary carbohydrates. The most common aetiological microbiological agents of enamel caries are considered to be Streptococcus mutans and Streptococcus sobrinus. Additional associated microorganisms are lactobacilli and actinomyces, 
the former being considered as secondary invaders, while the latter being responsible for root surface caries [3-6]. The pathogenesis of dental caries is dependent upon the presence of fermentable sugars in the diet and the presence of cariogenic bacterial species. The main virulence properties of S. mutans and S. sobrinus are their ability to adhere to the tooth surface together with their rapid metabolism of sucrose to organic acids and to extracellular polysaccharides.

Several approaches to caries prevention are possible: (i) elimination of dietary carbohydrates from the diet, (ii) elimination of the causative organisms, (iii) prevention of bacterial adhesion and/or plaque formation, (iv) interference with bacterial metabolism, for example, by fluorides, and (v) enhancing acid resistance of the tooth enamel, for example, by fluoride [7-12]. Chemicals able to achieve one or more of the above have been shown to be present in a number of foods. In some foods the presence of compounds with antibacterial activity against different pathogens has been detected; in other foods both antiadhesive activity and inhibitory activity against the extracellular polysaccharide have been demonstrated. Recently, the anticariogenic properties of food components have been verified in vivo using both animals and humans tests. For example, extracts obtained from different teas and their polyphenol components have been investigated thoroughly for their activity. Polyphenols in tea have been shown to reduce caries development in animals because they decrease the cell surface hydrophobicity of $S$. mutans and the ability of the organism to synthesize adherent water-insoluble glucan from sucrose [13-17]. Additionally propolis [18] has been shown to possess both antimicrobial and GTF-inhibitory activities. The extract from Lentinus edodes, an edible mushroom, was studied in rats [19] and found to have an inhibitory effect on waterinsoluble glucan formation by GTF. The same inhibitory effects have been shown by apple procyanidins [20]. High molecular weight components of hop bract inhibit adherence of water-insoluble glucan synthesis by $S$. mutans [21]. The cariostatic activity of cacao mass extract has been observed in vitro and in animal experiments. In this case, high molecular weight polyphenolic compounds and unsaturated fatty acids were shown to be the active constituents. The former, which showed strong anti-GTF activity, were polymeric epicatechins in an acetylated form. The latter showed bactericidal activity against $S$. mutans [22, 23]. An interesting antibacterial activity has been detected in coffee that is effective against $S$. mutans as well as other Gram-positive bacteria and some Gram-negative species [24-26]. In particular, it has been shown that roasted coffee interferes with streptococcal sucrose-independent adsorption to hydroxyapatite (HA) beads. Such activity may be due to not only small molecules occurring naturally, such as trigonelline, nicotinic and chlorogenic acids, but also to coffee components containing condensed polyphenols or melanoidins that occur during the roasting process [27].

Periodontal diseases are a heterogeneous group of inflammatory conditions that involve the supporting tissues of the teeth. They include gingivitis, in which only the gingiva is involved, and the various forms of periodontitis in which destruction of alveolar bone occurs. Characteristically, in these diseases, the junctional epithelial tissue at the base of the gingival crevice migrates down the root of the tooth with the result of the formation of a periodontal pocket. The initiation and progression of periodontal diseases is attributed to the presence of elevated levels of pathogenic bacteria within the gingival crevice. Any of several hundred bacterial species may inhabit the gingival crevice; however, it has been shown that only a few play a significant role in the aetiology of the various periodontal diseases. Indeed, it is generally accepted that a consortium of bacteria, not a single species, is involved in these diseases.

Gingivitis is the most prevalent form of periodontal disease and a disease which can be prevented and alleviated by the topical application of suitable agents in oral hygiene products such as toothpastes and mouthwashes. Accumulation of dental plaque at gingival margins due to inadequate dental hygiene leads to the inflammation of the gingivae, defined as gingivitis [28]. It can be defined as a nonspecific inflammatory process of the gingivae (gums) without destruction of the supporting tissues. This is a reversible condition as a return to meticulous dental hygiene practices will restore gingival health [29]. The plaque biofilm on the surfaces of teeth at the gum margin can cause inflammation. Several bacterial species have been implicated as aetiological agents of this disease. These include Actinomyces israelii, A. naeslundii, A. odontolyticus, Lactobacillus spp., Prevotella spp., Treponema spp., and Fusobacterium nucleatum. A key trend observed during gingivitis is the ascendancy of Actinomyces spp. and Gram-negative rods at the expense of Streptococcus spp. Gingivitis affects $100 \%$ of the adult population at some point during their lives, and, in some cases, it can lead to the development of periodontitis (although this can occur in individuals without any gingivitis) which results in loss of attachment of the gingivae to the teeth, a condition causing major discomfort and tooth loss, and necessitates extensive and costly dental treatment.

In comparison with caries, there is considerably less information available regarding the effects of beverages/ foods on periodontal diseases. Possible ways in which such materials could prevent or alleviate gingivitis would be by directly killing the causative organisms, interfering with the formation of plaque at the gingival margin, disrupting preformed plaque, attenuating the virulence of the causative organisms, and acting as free radical scavengers thereby reducing the plaque-induced inflammation. Diets rich in vitamin $\mathrm{C}$ have long been known to protect against gingivitis [30]. Folate also appears to protect against the disease [31]. Green tea polyphenols have in vitro inhibitory effects on the adhesion of oral bacteria to epithelial cells [32]. Furthermore, it has been shown that the high molecular weight material of cranberry juice is effective in inhibiting coaggregation between different causative bacteria and Fusobacterium nucleatum [33]. Adhesion of streptococci is inhibited by hop bract polyphenols [34] and by several tea materials [16, 35] that have also been shown to inhibit water-insoluble glucan synthesis and bacterial amylases. An interesting antibacterial activity has been detected in coffee [24-27].

The aim of this work was to select foods and beverages from the folk literature and using the knowledge of 
the authors that had anti-caries and anti-gingivitis activities and to characterize and identify the active ingredients.

\section{Materials and Methods}

2.1. Test Materials. The selection of which foods and beverages investigated was based on an extensive literature search (PubMed, Web of Science, Medline) together with the expertise and knowledge of the authors. The following foods and beverages were selected for investigation: Green and Black tea (Camellia sinensis), Cranberry juice (Vaccinium macrocarpon; Ocean Spray, Lakeville-Middleboro, MA), Raspberries (Rubus idaeus), Shiitake mushrooms (Lentinula edodes), Red chicory (Cichorium intibus. var. Silvestre-Radicchio di Treviso tardivo IGP), and Beer (Guinness; Diageo PLC, London).

Homogenates/extracts of the selected foods/beverages were prepared and chemically analysed to provide material suitable for subsequent investigations. For each food/beverage an operative protocol was prepared. This enabled the identification of the critical points that could influence the chemical composition of the extracts and therefore their biological properties [36].

2.2. Initial Fractionation of Homogenates. Fractionation of raspberry, shiitake mushroom, and chicory extracts was carried out by ultrafiltration or dialysis to provide a low molecular mass (LMM) fraction and high molecular mass (HMM) fraction for subsequent bioassay [36].

The HMM and LMM fractions of all three homogenates were subjected to a range of in vitro microbiological assays selected to determine their potential antigingivitis or anticaries properties (as described below).

2.3. Assessment of the Homogenates, Extracts for Antigingivitis Activities and Anticaries Activities. In order to evaluate the extracts for their potential anti-gingivitis activities, a number of high-throughput assays were designed for use in the study. These involved organisms associated with gingivitis and with oral health (Streptococcus sanguinis, Actinomyces naeslundii, Fusobacterium nucleatum, Prevotella intermedia, Veillonella dispar, and Neisseria subflava).

Additionally, to test the extracts for their potential anticaries activities, a number of high-throughput assays were designed for use in the study. These involved organisms associated with caries and with oral health (S. sanguinis, $S$. mutans, L. casei, V. dispar, and N. subflava).

The tests used to evaluate the homogenates/extracts were as follows.

The assays used for anti-gingivitis and anti-caries effects were as follows:

(1) prevention of biofilm formation by the target organisms,

(2) determining antibacterial effect against the target organisms,

(3) prevention of coaggregation by the target organisms,

(4) disruption of preexisting biofilms of the target organisms.
The assays used to specifically evaluate anti-gingivitis activity were as follows:

(5) prevention of adhesion to, and invasion of, gingival epithelial cells by those target organisms associated with gingivitis,

(6) inhibition of bacteria-induced host cell proinflammatory cytokine production by those target organisms associated with gingivitis.

The assays used to specifically evaluate anti-caries activity were as follows:

(7) prevention of adhesion of the target organisms to, and induce detachment from, hydroxyapatite,

(8) disruption of signal transduction in S. mutans,

(9) inhibition of acid production by caries-associated organisms.

2.3.1. Prevention of Biofilm Formation by the Target Organisms. The capability of the selected homogenates/extracts, at different concentrations, to prevent biofilm formation was evaluated by the microtitre plate assay described here in after.

All bacteria were cultured in Brain Heart Infusion broth (BHIB) except for $S$. mutans which was grown in BHIB $(\times 0.5)$ supplemented with sucrose (final concentration, $0.2 \%)$. Cultures were incubated at $37^{\circ} \mathrm{C}$ in $5 \% \mathrm{CO}_{2}$ /air $(S$. mutans, S. sanguinis, and L. casei) or under anaerobic conditions (P. intermedia, A. naeslundii, and $V$. dispar).

Bacterial suspensions were prepared in the appropriate growth medium containing different concentrations of the test material ( $\mathrm{pH}$ adjusted to 7 ). The final concentration of bacteria was either $3-5 \times 10^{5} \mathrm{cfu} \mathrm{mL}^{-1}$ (S. mutans, $S$. sanguinis, $L$. casei, $V$. dispar, and $A$. naeslundii) or $5-8 \times$ $10^{6} \mathrm{cfu} \mathrm{mL}^{-1}$ (P. intermedia). Aliquots $(200 \mu \mathrm{L})$ of the cell suspensions were inoculated into the wells of 96-well polystyrene microtiter plates. For each strain, test materialuntreated controls were included. Plates were then incubated at $37^{\circ} \mathrm{C}$ up to one week in either $5 \% \mathrm{CO}_{2} /$ air (S. mutans, $S$. sanguinis, and $L$. casei) or anaerobic conditions (P. intermedia, A. naeslundii, and $V$. dispar), with incubation media changed every $24 \mathrm{~h}$ and every $48 \mathrm{~h}$ for aerobic and anaerobic bacteria, respectively. Biofilm formation was quantified after $48 \mathrm{~h}$ and 7-day incubation. To this end, the growth medium was removed by aspiration; wells were gently washed with water and air dried; adherent bacteria were then stained with $0.01 \%$ crystal violet $(100 \mu \mathrm{L})$. After 15 min incubation at room temperature, wells were gently washed with water, and bound dye was extracted from stained cells by adding $200 \mu \mathrm{L}$ of ethanol: acetone $(8: 2)$. Biofilm formation was quantified by measuring the absorbance of the solution at $540 \mathrm{~nm}$. Biofilm inhibitory activity was evaluated as a proportion of untreated controls (100\%). Experiments were run in triplicate and were performed twice.

2.3.2. Antibacterial Activity of Homogenates/Extracts. All the extracts were assayed for their antibacterial activities in a standard Minimum Inhibitory Concentration (MIC) assay. 
Bacteria were grown in $5 \mathrm{~mL}$ tubes at $37^{\circ} \mathrm{C}$ either aerobically at ambient air or under anaerobic conditions (GasPack Anaerobic System, Becton, and Dickinson) in BHIB. After overnight growth, the bacterial culture was diluted in broth to contain $10^{5} \mathrm{cfu} / \mathrm{mL}$. Twofold dilutions of test samples and fractions in $0.1 \mathrm{~mL}$ of BHIB were placed into wells of flat-bottomed microtitre plates (Nunc 96-well flat-bottomed microtitre plates). A $10 \mu \mathrm{L}$ volume of bacterial culture was then added. Following incubation of the plates for $18 \mathrm{~h}$ at $37^{\circ} \mathrm{C}$ in ambient air or anaerobically as described previously, the MICs were determined. The MICs were recorded as the lowest concentration or dilution of test sample or fraction that completely inhibited visible growth of the bacteria.

2.3.3. Prevention of Coaggregation of Target Organisms. All combinations of the strains used were tested for coaggregation activity and the following is used in subsequent assays: S. sanguinis snd $P$. intermedia, S. sanguinis and F. nucleatum, $N$. subflava and F. nucleatum, S. sanguinis and V. dispar, $S$. sanguinis and N. subflava, S. sanguinis and S. mutans and $S$. mutans and L. casei.

The homogenates/extracts were assayed for their ability to inhibit coaggregation as described as follows.

Bacteria were grown in $5 \mathrm{~mL}$ tubes at $37^{\circ} \mathrm{C}$ either aerobically at ambient air or under anaerobic conditions (GasPack Anaerobic System, Becton, and Dickinson) in BHIB. After overnight growth, cells were harvested, washed with coaggregating buffer ( $1 \mathrm{mM}$ tris (hydroxy-methyl) aminomethane; $0.1 \mathrm{mmol} / \mathrm{L}$ magnesium chloride; $0.1 \mathrm{mmol} / \mathrm{L}$ sodium chloride; 0.02 percent sodium azide adjusted to $\mathrm{pH}, 8.0$ ), adjusted to an optical density of 1.5 at $400 \mathrm{~nm}$ (UV-Vis. Spectrophotometer), and stored at $4^{\circ} \mathrm{C}$ until use. The ability of test sample or fraction to inhibit coaggregation of selected pairs of bacteria was tested by adding equal volumes $(0.05 \mathrm{~mL})$ of bacterial suspension of one pair to equal volume of serial twofold dilution of test sample or fraction in coaggregating buffer followed by adding equal volume of the bacterial suspension of the other coaggregating member in $12 \times 75 \mathrm{~mm}$ test tube. After vigorous vortex of the mixture and further incubation at room temperature for 2 min coaggregation was scored according Cisar et al. [37]. The last dilution of the sample causing complete inhibition of coaggregation was recorded and expressed either as final concentration (w/v) or as per cent of undiluted sample.

2.3.4. Disruption of Preexisting Biofilms of the Target Organisms. Mature biofilms of each of the test organisms were grown on cellulose nitrate membrane filters and incubated with the test compounds for $1 \mathrm{~min}$. The number of live and dead cells disrupted from the biofilm was assessed as well as the number of live and dead cells remaining following the protocol described by Bryce et al. [38].

\subsubsection{Prevention of Adhesion to, and Invasion of, Gingival Epithelial Cells}

Adherence to KB22 Cells. The capability of the selected food/ beverages to inhibit bacterial adherence to KB22 monolayers was evaluated using three experimental approaches: (a) labeled bacteria in PBS with the tested compounds were added to monolayers; (b) monolayers were pretreated with the tested compounds and then incubated at $37^{\circ} \mathrm{C}$; (c) labeled bacteria, grown in medium supplemented with the tested compound, were added to the monolayers. Before performing the described experiments, the toxicity of the tested compound at $2 \mathrm{x}$ and $1 \mathrm{x}$ concentrations towards $\mathrm{KB}$ cells after 1 and $2 \mathrm{~h}$ incubation was tested by trypan blue exclusion.

Bacterial Growth and Labeling. All bacteria were cultured in BHIB except for $S$. mutans which was grown in BHIB $(0.5 \mathrm{x})$ supplemented with sucrose (final concentration, $0.2 \%$ ). Cultures were incubated at $37^{\circ} \mathrm{C}$ in $5 \% \mathrm{CO}_{2}$ /air (S. mutans, $S$. sanguinis, and L. casei) or under anaerobic conditions ( $P$. intermedia, A. naeslundii, and $V$. dispar). To radiolabel bacteria, $10 \mu \mathrm{Ci}$ [methyl ${ }^{3} \mathrm{H}$ ] thymidine $\left(25 \mathrm{Ci} \mathrm{mmol}^{-1}\right) \mathrm{mL}^{-1}$ was added to the growth medium. Cells were harvested at stationary phase by centrifugation $(5,000 \times \mathrm{g}$ for $10 \mathrm{~min}$ at $4^{\circ} \mathrm{C}$ ) and washed twice with $10 \mathrm{mM}$ phosphate buffer $(\mathrm{PB})$, $\mathrm{pH}$ 7.0; pellets were resuspended in either $10 \mathrm{mM} \mathrm{PB}, \mathrm{pH} 7.0$, or BHIB or phosphate buffered saline (PBS: $0.1 \mathrm{M} \mathrm{Na}_{2} \mathrm{HPO}_{4}$, $0.1 \mathrm{M} \mathrm{KH}_{2} \mathrm{PO}_{4}, 0.15 \mathrm{M} \mathrm{NaCl}, \mathrm{pH} 7.2$ to 7.4 ), depending on the test to be performed. Cell bound radioactivity was quantified with a liquid scintillation counter. Cell labeling efficiency (number of bacteria per count per min) was then determined.

Cell Culture. Gingival fibroblast $\mathrm{KB}$ cell line (accession number ICLC HTL96014) obtained from Cell bank Interlab Cell Line Collection (ICLC) of IST-Istituto dei Tumori di Genova (Genoa, Italy) was cultured in a complete medium consisting of Dulbecco's Modified Eagle's Medium (DMEM) high glucose, with $4500 \mathrm{mg} \mathrm{L}^{-1}$ glucose and sodium bicarbonate supplemented with $10 \%$ foetal calf serum, penicillin $\left(100 \mathrm{U} \mathrm{mL}^{-1}\right)$, streptomycin $\left(100 \mu \mathrm{g} \mathrm{mL}^{-1}\right)$, and $2 \mathrm{mM} \mathrm{L}$ glutamine. Cells were incubated at $37^{\circ} \mathrm{C}$ in a $5 \% \mathrm{CO}_{2}$ atmosphere to about $90 \%$ confluence and used after 5-10 passages. For bacterial adherence experiments, monolayers prepared in 96 well, flat bottom microtitre plates, were washed twice before use with PBS.

Adherence to KB Cell Line. The effect on bacterial adherence to $\mathrm{KB}$ cells of unfractionated whole material was tested. KB monolayers were prepared in 96 well, flat bottom microtiter plates, using Dulbecco's Modified Eagle's Medium (DMEM) high glucose prepared as described previously without antibiotics; before the assay, monolayers were washed twice with PBS (0.1 $\mathrm{M} \mathrm{Na}_{2} \mathrm{HPO}_{4}, 0.1 \mathrm{M} \mathrm{KH}_{2} \mathrm{PO}_{4}, 0.15 \mathrm{M} \mathrm{NaCl}, \mathrm{pH}$ 7.2 to 7.4). Suspensions of labeled bacteria (A. naeslundii) were prepared in PBS containing different concentrations of test materials ( $\mathrm{pH}$ adjusted to 7) (final bacterial concentration, $\left.4-6 \times 10^{8} \mathrm{cfu} \mathrm{mL}^{-1}\right)$. Aliquots $(100 \mu \mathrm{L})$ of the bacterial suspensions were added to $\mathrm{KB}$ monolayers and incubated at $37^{\circ} \mathrm{C}$ for $1 \mathrm{~h}$ in $5 \% \mathrm{CO}_{2}$ atmosphere with gentle shaking. For each strain, untreated controls were included. After incubation, cells were disrupted by adding $200 \mu \mathrm{L}$ of 
cold distilled water, and lysates were transferred to PICOFLUOR 15 scintillation fluid (Packard Instruments Company Inc., Ill.). Radioactivity was assayed in a liquid scintillation counter and, by the use of cell labeling efficiency, the number of bacteria per monolayer was evaluated. The inhibitory activity of the test materials was gauged by comparing fraction treated samples to the respective untreated controls $(100 \%)$. Controls without bacteria were always included to evaluate KB cell viability in the presence of the test materials by trypan blue exclusion. Experiments were run in triplicate and were performed at least twice.

Inhibition of Bacterial Internalization. The capability of the selected homogenates/extracts to inhibit bacterial internalization into KB22 monolayers was evaluated; before performing the described experiments, the toxicity of the tested compound at $2 \mathrm{x}$ concentration towards KB cells after $5 \mathrm{~h}$ incubation was tested by trypan blue exclusion. Only mushroom showed toxicity (even at very low concentrations) and was not used.

KB Cell-Invasion Assay. KB monolayers were prepared in $16 \mathrm{~mm}$ well of 24-well tissue culture plates, in Dulbecco's Modified Eagle's Medium (DMEM) high glucose prepared as above without antibiotics; before the assay, monolayers were washed twice with PBS. Bacterial suspensions (P. intermedia and $A$. naeslundii) were prepared in $\mathrm{KB}$ cell growth medium without antibiotics, containing different concentrations of the test materials ( $\mathrm{pH}$ adjusted to 7) (final bacterial concentration, $\left.6-8 \times 10^{7} \mathrm{cfu} \mathrm{mL}^{-1}\right)$, and added $(1 \mathrm{~mL})$ to monolayers. For each strain, fraction untreated controls were included. After $90 \mathrm{~min}$ incubation at $37^{\circ} \mathrm{C}$ in $5 \% \quad \mathrm{CO}_{2}$ atmosphere with gentle shaking, monolayers were washed with PBS to remove nonadherent bacteria. To evaluate total cultivable bacteria per monolayer, cells were disrupted by adding $1 \mathrm{~mL}$ of cold distilled water. Suitable dilutions of the lysates were plated onto Fastidious Anaerobe Agar (FAA; Biogenetics, Italy) plus $5 \%(\mathrm{v} / \mathrm{v})$ defibrinated horse blood; after $36-48 \mathrm{~h}$ incubation under anaerobic conditions, colonyforming units were counted. To evaluate cultivable internalized bacteria per monolayer, external bacteria were killed by covering monolayers with cell growth medium containing bactericidal concentrations of gentamicin $\left(300 \mu \mathrm{g} \mathrm{mL}^{-1}\right)$, metronidazole $\left(200 \mu \mathrm{g} \mathrm{mL}^{-1}\right)$, and penicillin $\left(5 \mu \mathrm{g} \mathrm{mL}^{-1}\right)$. After 90 min incubation at $37^{\circ} \mathrm{C}$ in $5 \%$ carbon dioxide, cells were extensively washed and lysed in cold distilled water. Suitable dilutions of the lysates were plated as above and colony-forming units of internalized bacteria were counted after incubation. Cell-invasion efficiency was measured by comparing internalized cultivable bacteria per monolayer to total cultivable bacteria per monolayer (100\%). The inhibitory activity of the test materials was gauged by comparing fraction treated samples to the respective untreated controls. Each strain was tested in three separate assays on different days; each assay represented the average of triplicate wells. Controls without bacteria were always included to evaluate $\mathrm{KB}$ cell viability by Trypan blue assay in the presence of the test materials.
2.3.6. Inhibition of Host Cell Proinflammatory Cytokine Production Induced by the Target Organisms. The ability of the test materials to inhibit cytokine production by monoMac 6 cells (a human monocytic cell line) in response to bacteria (F. nucleatum and P. intermedia) was evaluated.

Maintenance of Mono-Mac-6 Cells. The myelomonocytic cell line Mono-Mac-6 was maintained in RPMI-1640 medium containing $2 \mathrm{mM} \mathrm{L}$-glutamine, 5\% heat-inactivated FCS, insulin $(9 \mathrm{mg} / \mathrm{mL})$, oxaloacetic acid $(1 \mathrm{mM})$, sodium pyruvate $(1 \mathrm{mM})$, and nonessential amino acids ( $0.1 \mathrm{mM}$, Sigma). Cells were cultured in $75-\mathrm{cm}^{2}$ flasks at $37^{\circ} \mathrm{C}$ in a humidified atmosphere of $5 \% \mathrm{CO}_{2}$ in air. Weekly, cells were split at a ratio of $1: 5$ by centrifugation at $1500 \times \mathrm{g}$ for $5 \mathrm{~min}$ and resuspended in fresh medium. Cells were then fed with fresh medium once a week.

Inhibition of Bacteria-Induced Host Cell Proinflammatory Cytokine Production. Mono-Mac-6 cells were centrifuged at $1500 \times \mathrm{g}$ for $5 \mathrm{~min}$ and resuspended in media with $2 \%(\mathrm{v} / \mathrm{v})$ FCS. The viable cells were dispensed into 24-well tissue culture plates at $2 \times 10^{6} / 500 \mu \mathrm{L} /$ well. The selected test or control agent (in triplicate) was then added to cells neat and at dilutions of $1: 10$ and $1: 100$. Bacterial strains were inoculated into $10 \mathrm{~mL}$ of the appropriate broth and grown in appropriate conditions. Bacterial cultures were then diluted in fresh broth and grown to exponential growth stage, as determined spectrophotometrically. At this point, an aliquot of the bacterial suspension was removed to determine the number of bacteria added to Mono-Mac- 6 cells retrospectively. The aliquot was serially diluted and plated onto appropriate agar. After 5-day incubation under the appropriate conditions, plates were counted to determine the $\mathrm{CFU} / \mathrm{mL}$ used in the experiment.

Bacteria were pelleted by centrifugation, washed with PBS, repelleted by centrifugation, and resuspended in RPMI1640. Bacteria were then added to wells containing MonoMac- 6 cells to obtain a multiplicity of infection of 1,10 , and 100 bacteria to 1 Mono-Mac- 6 cell (each in triplicate). The number of bacteria added to Mono-Mac- 6 cells was judged on the OD of bacterial cultures and previously determined $\mathrm{CFU} / \mathrm{mL}$ at a particular OD (data not shown). Mono-Mac6 cell numbers for each experiment were determined by centrifugation of contents of tissue culture plate well and the cells counted using a haemocytometer. Bacteria were centrifuged onto the monolayer at $2000 \times \mathrm{g}$ for $10 \mathrm{~min}$ at room temperature and then plates incubated at $37^{\circ} \mathrm{C}$ in an atmosphere containing $5 \% \mathrm{CO}_{2}$ for $5 \mathrm{~h}$.

For determination of cytokine release at the end of the culture period cytokines released into the medium were assayed by in-house ELISA for IL-6 commercially available kit for the detection of IL-6.

2.3.7. Prevention of Adhesion to, and Induction of Detachment from, Hydroxyapatite (HA). The capability of the selected homogenates/extracts to prevent bacterial adhesion to HA beads was evaluated following three experimental approaches: (a) the tested compound and the radiolabelled 
bacterial suspensions were added simultaneously to saliva coated beads; (b) saliva coated beads were pretreated with the tested compounds; (c) labeled bacteria grown in THB supplemented with the test material (at 1/2 MIC) were added to the beads. In the case of green tea and cranberry, their activity was evaluated following approach "a" only.

\section{Bacterial Growth and Labeling. See Section 2.3.5.}

Preparation of Hydroxyapatite (HA) Beads. Fifty mg aliquots of spheroidal HA beads (Sigma Aldrich, UK) were washed with $1 \mathrm{mM} \mathrm{PB}, \mathrm{pH} 7.0$, in glass tubes and autoclaved. Beads were collected by centrifugation $\left(100 \times \mathrm{g}, 1 \mathrm{~min}, 4^{\circ} \mathrm{C}\right)$ and equilibrated in $1 \mathrm{mM} \mathrm{PB}, \mathrm{pH} 7.0$ ( $1 \mathrm{~h}$ at room temperature). $\mathrm{HA}$ was then treated ( $1 \mathrm{~h}$ at room temperature) with $200 \mu \mathrm{L}$ undiluted saliva, which was collected from unstimulated donors, clarified by centrifugation $(15,000 \times \mathrm{g}$ for $30 \mathrm{~min}$ at $4^{\circ} \mathrm{C}$ ), and sterilized through $0.22 \mu \mathrm{m}$ nitrocellulose membrane filters. Beads were then collected by centrifugation as above and washed with $10 \mathrm{mM} \mathrm{PB}, \mathrm{pH}$ 7.0.

Bacterial Adherence to HA Beads. The effect on bacterial adherence to HA beads of unfractionated whole materials was tested. Suspensions of labeled bacteria were prepared in $10 \mathrm{mM} \mathrm{PB}, \mathrm{pH} 7.0$, containing different concentrations of the test materials ( $\mathrm{pH}$ adjusted to 7 ) (final bacterial concentration, $\left.6-8 \times 10^{7} \mathrm{cfu} \mathrm{mL}^{-1}\right)$. Aliquots $(1 \mathrm{~mL})$ of the cell suspensions were added to saliva coated HA beads $(50 \mathrm{mg})$ in polypropylene microfuge tubes and incubated at room temperature on Rotomix test tube rotator (TKA Technolabo ASSI, Italy). Controls (no test material added) were included in all treatments. After $1 \mathrm{~h}$ incubation, the beads were collected by centrifugation $\left(100 \times \mathrm{g}, 1 \mathrm{~min}, 4^{\circ} \mathrm{C}\right)$, washed twice with $10 \mathrm{mM}$ PB to remove nonadherent bacteria, and transferred to PICO-FLUOR 15 scintillation fluid (Packard Instruments Company Inc., III.). Radioactivity was assayed in a liquid scintillation counter and, on the basis of cell labeling efficiency, the number of bacteria adhering to HA beads $(50 \mathrm{mg}$ ) was evaluated. The inhibitory activity of the test materials was gauged by comparing test material-treated samples to the respective untreated controls (100\%). Controls for bacterial settling due to aggregation were also included; the amount of settled bacteria was always $<1 \%$ of the inoculum. Experiments were run in triplicate and were performed at least twice.

Induction of Detachment from HA Beads. Aliquots $(1 \mathrm{~mL})$ of cell suspensions, prepared in $10 \mathrm{mM} \mathrm{PB}, \mathrm{pH} 7.0$, were added to saliva-coated HA beads $(50 \mathrm{mg}$ ) and incubated at room temperature on a Rotomix test tube rotator (final bacterial concentration, $\left.6-8 \times 10^{7} \mathrm{cfu} \mathrm{mL}^{-1}\right)$. After $1 \mathrm{~h}$ incubation, the beads were collected by centrifugation $(100 \times \mathrm{g}, 1 \mathrm{~min}$, $4^{\circ} \mathrm{C}$ ) and washed twice with $10 \mathrm{mM} \mathrm{PB}, \mathrm{pH} 7.0$, to remove nonadherent bacteria. HA was then resuspended in the same buffer $(1 \mathrm{~mL})$ supplemented with different concentrations of the test compounds ( $\mathrm{pH}$ adjusted to 7 ) and incubated at room temperature on a Rotomix test tube rotator. Untreated control samples were included. Other samples were included to assess total HA-bound bacteria, as described previously. Immediately after beads resuspension (time zero) and after 1 and $2 \mathrm{~h}$ incubation, the mixtures were centrifuged $(200 \times \mathrm{g}$, $5 \mathrm{~min}, 4^{\circ} \mathrm{C}$ ), and the supernatants were transferred to PICOFLUOR 15 scintillation fluid. Radioactivity was assayed in a liquid scintillation counter and, on the basis of cell labelling efficiency, the number of bacteria present in the supernatant, corresponding to detached cells, was evaluated. The percent of detached versus total HA-bound bacteria was determined. The effect of the tested compounds was evaluated by comparing treated samples with the untreated controls. Experiments were run in triplicate and were performed at least twice.

2.3.8. Effect on Signal Transduction. The effect of homogenates/extracts on $S$. mutans comDE gene expression was determined as described here in after:

S. mutans cells were grown in $\mathrm{BHIB}$ at $37^{\circ} \mathrm{C}, 5 \% \mathrm{CO}_{2}$ to the early log phase, $\mathrm{OD}_{600}=0.2$. The inoculum was exposed to the tested homogenates/extracts in BHI for $2 \mathrm{~h}$. Total RNA was extracted from the S. mutans cells. After being exposed to the tested agents, the above bacterial suspension was centrifuged, washed with PBS, and resuspended in TriReagent (Sigma-Aldrich) [39]. The bacteria were disrupted with the aid of glass beads (Sigma-Aldrich) in a Fast Prep cell disrupter (Bio 101, Savant Instrument Inc., NY, USA). The suspensions obtained were centrifuged and the RNAcontaining supernatant was transferred to a new microcentrifuge tube. The homogenate was supplemented with BCP-phase separation reagent (Molecular Research Center, Cincinnati, OH, USA), and the upper aqueous phase, containing the RNA, was precipitated with isopropanol. The RNA pellet was washed with ethanol, centrifuged, and the purified RNA was resuspended in diethyl pyrocarbonatetreated water (Invitrogen, Carlsbad, CA, USA). Due to the sensitivity of the PCR, residual contaminating DNA was removed by RNase-free DNase [40]. The RNA concentration was determined spectrophotometrically according to the $A_{260} / A_{280}$ ratio, using a Nanodrop. The integrity of the RNA was assessed by $1.5 \%$ agarose gel electrophoresis.

Reverse transcription and quantitative real-time PCR were performed as described previously [41]. Briefly, a reverse transcription (RT) reaction mix $(20 \mu \mathrm{L})$ containing $50 \mathrm{ng}$ of random hexamers, $10 \mathrm{mM}$ dNTPs mix, and $1 \mu \mathrm{g}$ of total RNA sample was incubated at $65^{\circ} \mathrm{C}$ for $5 \mathrm{~min}$ and then placed on ice. $\times 10$ RT buffer, $25 \mathrm{mM} \mathrm{MgCl}_{2}, 0.1 \mathrm{M}$ DTT, $40 \mathrm{U}$ of RNaseOUT Recombinant Ribonuclease Inhibitor, and $50 \mathrm{U}$ of Super Script II RT (Invitrogen) were added to the reaction mix in each tube. After incubation at $25^{\circ} \mathrm{C}$ for $10 \mathrm{~min}$, the tubes were transferred to $2^{\circ} \mathrm{C}$ for $50 \mathrm{~min}$. The reaction was terminated by heating the mixture at $70^{\circ} \mathrm{C}$ for $15 \mathrm{~min}$, and the cDNA samples were stored at $-20^{\circ} \mathrm{C}$ until used.

Real-time qPCR was performed using the ABI PRISM 7000 Sequence Detection System (Applied Biosystems, Foster City, CA, USA) with an SYBR Green PCR Master Mix (PE Applied Biosystems). The reaction mix $(20 \mu \mathrm{L})$ contained $1 \mu \mathrm{L}$ of the cDNA sample and $0.5 \mu \mathrm{M}$ of the appropriate PCR primer. The cycle profile was as follows: 1 cycle at $50^{\circ} \mathrm{C}$ for $2 \mathrm{~min}, 1 \mathrm{cycle}$ at $95^{\circ} \mathrm{C}$ for $1 \mathrm{~min}$, and 30 cycles at $95^{\circ} \mathrm{C}$ 
for $15 \mathrm{sec}$ and at $60^{\circ} \mathrm{C}$ for $1 \mathrm{~min}$, following a dissociation stage: a $15 \mathrm{sec}$ hold at $95^{\circ} \mathrm{C}$ and at $20 \mathrm{sec}$ for $20 \mathrm{sec}$, and a slow ramp (20 min) from 60 to $95^{\circ} \mathrm{C}$. The critical threshold cycle $\left(C_{T}\right)$ was defined as the cycle at which fluorescence becomes detectable above the background and is inversely proportional to the logarithm of the initial number of template molecules. A standard curve was plotted for each primer set with $C_{T}$ values obtained from amplification of known quantities of cDNA from S. mutans GS5. The standard curve was used for transformation of the $C_{T}$ values to the relative number of cDNA molecules.

Data were expressed as the mean plus standard deviation of triplicate experiments. Contamination of genomic DNA was measured in control reactions devoid of reverse transcriptase. The same procedure was applied to all the primers.

The com $C / D / E$ primers were designed by using the algorithms provided in Primer Express (Applied Biosystems). For each set of primers a standard amplification curve was drawn. Only curves with slope $\approx-3$ were accepted as reliable primers. The primer set $16 \mathrm{~S}-\mathrm{F} / \mathrm{R}$, corresponding to the $16 \mathrm{~S}$ rRNA gene of S. mutans (Acc. No. X58303), was designed to correspond to the expression of the housekeeping gene. The data were presented as the effect of various agents on com $C / D / E$ mRNA expression and normalized by endogenous control of $16 \mathrm{~S}$ rRNA transcription [41]. They were presented in relative units compared with those of the control, grown in the absence of the tested agents to calculate the per cent inhibition of com $C / D / E$ mRNA expression by test fraction.

\subsubsection{Inhibition of Acid Production by Caries-Associated} Species. Caries is a multifactorial disease with low $\mathrm{pH}$ as a driving force for mineral dissolution. Plaque $\mathrm{pH}$ is lowered by organic acids (e.g., lactate, acetate, and propionate) that are released by oral bacteria as fermentation products. The ideal anticaries therapeutic agent would inhibit fermentation activity (acid production) of oral microorganisms, especially those that are known to be involved in caries aetiology, for example, S. mutans.

The effects of each homogenate/extract on acid production by the target organisms were carried out using an acidogenicity assay described by Damen et al. [42]. Biofilms of $S$. sanguinis, S. mutans, L. casei, and A. naeslundii were grown in 96-well microtiter plates and each was exposed to each test material and a positive and negative control. After incubation in glucose solution, biofilms were resuspended and sampled for organic acid content determination. Briefly, S. sanguinis, S. mutans, L. casei, and A. naeslundii were inoculated (streaked for single colonies) onto appropriate solid agar media to ensure purity. A single bacterial colony was picked and used to inoculate $5 \mathrm{~mL}$ of full-strength BHIB. This was incubated overnight yielding approximately $10^{9} \mathrm{CFU} / \mathrm{mL}$. The wells of 96-well flat-bottomed polystyrene microtiter plates (bio-one; Greiner, Frickenhausen, Germany) were inoculated with $10^{6} \mathrm{CFU} / \mathrm{mL}$ of the test organism in $0.2 \mathrm{~mL}$ of biofilm growth. Biofilms were grown in $10 \% \mathrm{H}_{2}, 10 \%$ $\mathrm{CO}_{2}$ in $\mathrm{N}_{2}$ at $37^{\circ} \mathrm{C}$. The medium was refreshed after $8 \mathrm{~h}$ and biofilms grown for another $16 \mathrm{~h}$ (in total for $24 \mathrm{~h}$ ). After $24 \mathrm{~h}$, the spent medium was carefully removed. $0.2 \mathrm{~mL}$ of the selected test or control agent (in quadruplicate) was applied to the biofilms as a neat and $1 / 10$ solution in water for $5 \mathrm{~min}$. Controls included a negative control of sterile water and a positive of $0.05 \%$ chlorhexidine solution. After careful removal of the test or control agent, the biofilms were rinsed three times with peptone-buffered water (PBW). Then the biofilms were incubated in $0.2 \mathrm{~mL}$ of $0.5 \%$ glucose solution at $37^{\circ} \mathrm{C}$ for $3 \mathrm{~h}$ in $10 \% \mathrm{H}_{2}, 10 \% \mathrm{CO}_{2}$ in $\mathrm{N}_{2}$. After the incubation period, the biofilms were suspended in the incubation fluid and sampled into precooled eppendorf tubes. The tubes were set on ice until further processing within one hour.

To release acids, all samples were heated at $80^{\circ} \mathrm{C}$ for $5 \mathrm{~min}$ and again cooled on ice [43]. Then the vials with plaque were centrifuged at $16,100 \times \mathrm{g}$ for $15 \mathrm{~min}$ at $4^{\circ} \mathrm{C}$. The supernatants were transferred into vials with a microspin filter (Ultrafree-MC $0.22 \mu \mathrm{m}$, Millipore, Bedford, Mass., USA) and centrifuged at $13,684 \times \mathrm{g}$ for $5 \mathrm{~min}$ at $4^{\circ} \mathrm{C}$. Filtered supernatants were stored at $-80^{\circ} \mathrm{C}$ until further processing.

Organic acids in the incubation fluid were determined as their anions by capillary electrophoresis on the Waters Capillary Ion Analyzer (Milford, Mass., USA) [42]. Sodium salts of formic, acetic, propionic, butyric, succinic, and lactic acid were used to prepare single and mixture standard solutions in MilliQ-water. Calibration curves were constructed for each acid separately. As an internal standard, $\mathrm{NaNO}_{3}$ was included in all samples. Formic, butyric, succinic, propionic, acetic, and lactic acids were determined in duplicate samples and expressed as nmol acid/sample in $0.2 \mathrm{~mL}$ of incubation fluid.

\section{Results and Discussion}

All test materials were tested for microbiological contamination before and after freeze drying or after juicing. No contamination was recorded.

3.1. Prevention of Biofilm Formation by the Target Organisms. Six species (V. dispar, F. nucleatum, A. naeslundii, P. intermedia, S. mutans, S. mutans (+ sucrose), and L. casei) were used to test 4 concentrations of extract $(2 \mathrm{x}, 1 \mathrm{x}, 0.5 \mathrm{x}$, and $0.25 \mathrm{x}$. Only $1 \mathrm{x}$ data shown) from cranberry, green tea, black tea, beer, raspberry, chicory, and mushroom. Even at the lowest concentration tested, all homogenates/extracts were able to inhibit biofilm formation by the target organisms to some extent although chicory was ineffective at inhibiting biofilm formation of $S$. mutans in the absence of sucrose (Table 1).

With regard to the gingivitis-associated species, F. nucleatum, A. naeslundii, and P. intermedia, the most active materials were Raspberry $=$ Chicory $=$ Mushroom $=$ Beer $>$ Black Tea $=$ Green tea $=$ Cranberry .

With regard to the caries-associated species, S. mutans $S$. mutans (+ sucrose) and L. Casei, the most active substances were Raspberry $>$ Green tea $=$ Black Tea $>$ Mushroom $>$ Beer $>$ Cranberry $=$ Chicory.

3.2. Antibacterial Activity of Homogenates/Extracts. All the extracts were assayed for their antibacterial activities in a standard Minimum Inhibitory Concentration (MIC) assay.

With regard to the gingivitis-associated species, $A$. naeslundii and $P$. intermedia, all extracts showed some inhibitory 


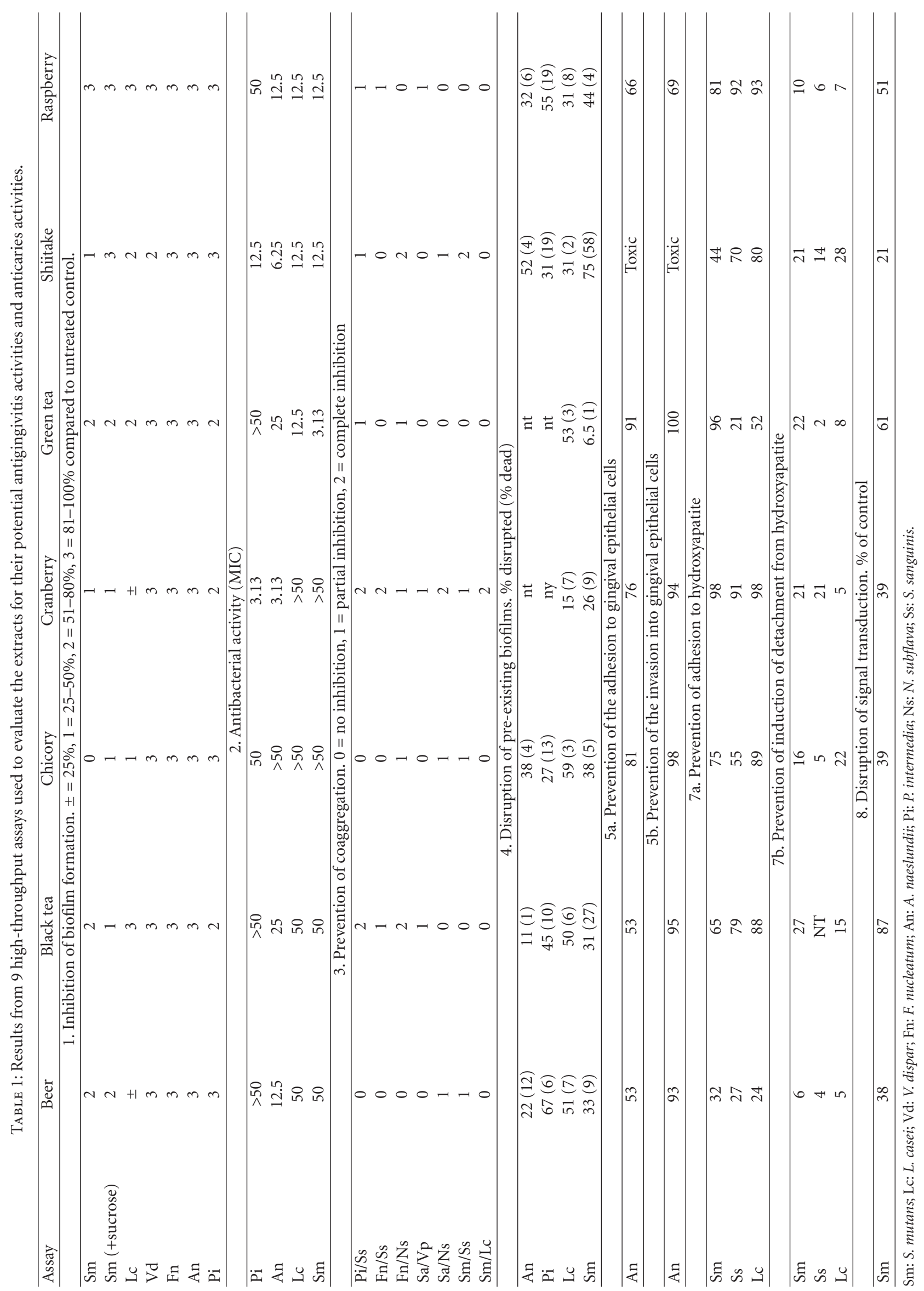


characteristics exhibiting MIC values ranging from $>50 \%$ to $3.13 \%$ (Table 1). The relative activities of the extracts against gingivitis-associated species were Cranberry $>$ Mushroom $>$ Raspberry $>$ beer $>$ Green Tea $=$ Black tea $>$ Chicory .

With regard to the caries-associated species $L$. casei and $S$. mutans, mushroom, raspberry, beer, and green tea exhibited some inhibitory activity. The relative activities of the extracts were Green Tea $>$ Raspberry $=$ Mushroom $>$ Beer $>$ Black Tea $>$ Chicory $=$ Cranberry.

3.3. Prevention of Coaggregation of Target Organisms. Coaggregation is an important factor when complex biofilm communities are being studied. Important relationships exist between certain strains which allow aggregation and biofilm formation. Inhibition of this may be an important factor in preventing biofilms forming. All homogenates/extracts showed some ability to inhibit coaggregation of at least one pair of target organisms (Table 1). With respect to gingivitisassociated organisms, the relative activities were Cranberry > Black Tea $>$ Mushroom $>$ Raspberry $=$ Green Tea $>$ Chicory $>$ Beer.

With regard to the caries-associated pairings the most effective at inhibiting coaggregation of these organisms was Cranberry $>$ Mushroom $>$ Chicory $=$ Beer.

\subsection{Disruption of Preexisting Biofilms of the Target Organ-} isms. Biofilms which build-up in low-shear environments such as those in interproximal regions and plaque within gingival margins are able to become well-established climax communities. These mature biofilms are more resistant to antimicrobials and antibiotics than biofilms forming in highshear systems.

The proportion (\%) of cells disrupted from the biofilm after $1 \mathrm{~min}$ incubation with the extracts and \% of dead cells were determined for the homogenates/extracts.

With respect to gingivitis-associated organisms (A. naeslundii and P. intermedia), all homogenates/extracts showed some ability to disrupt biofilms of the target organisms (Table 1). In many cases, a high proportion of the disrupted organisms were killed by the homogenates/extracts, the most active being beer which disrupted $67 \%$ of $P$. intermedia cells (6\% were dead) and the least active being black tea which disrupted $12 \%$ A. naeslundii cells (with $1 \%$ dead). Raspberry disrupted $55 \%$ of $P$. intermedia cells with $19 \%$ killed. The relative activities were Beer $>$ Raspberry $>$ Mushroom $>$ Chicory > Black Tea.

With respect to caries-associated organisms (L. casei and S. mutans), all homogenates/extracts were able to disrupt biofilms of both target organisms to some extent. Chicory, mushroom, beer, Black tea, and Raspberry were most active with between $30 \%$ and $75 \%$ disruption of biofilms $(<10 \%$ dead cells). Green tea and Cranberry were much less active.

3.5. Prevention of Adhesion to, and Invasion of, Gingival Epithelial Cells. The tested substances did not show cytotoxicity with the exception of mushroom. This was therefore used at $0.5 \mathrm{x}$ concentration (subcytotoxic). Species used in the prevention of adhesion assay was A. naeslundii. The most

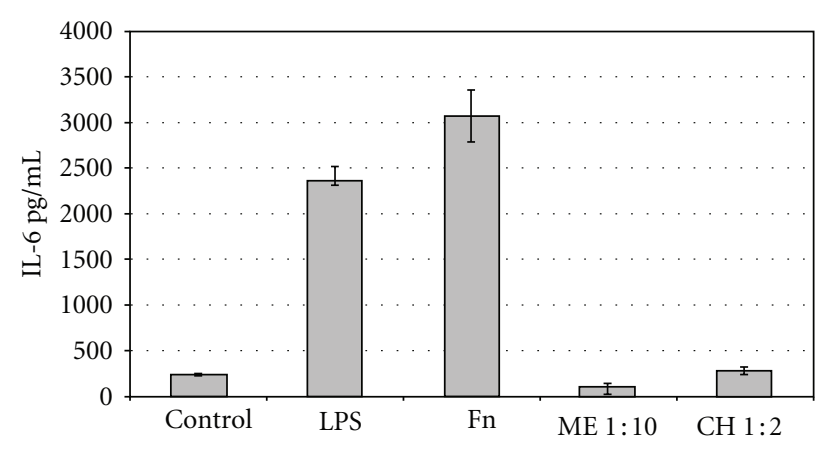

FIgURE 1: Graph showing the inhibition of IL-6 release from Mono-Mac-6 cells when challenged by LPS or F. nucleatum (Fn) supernatant and by dilutions of Chicory $(\mathrm{CH})$ and Mushroom (ME) homogenates.

active substance was shown to be Green Tea $>$ Chicory $>$ Raspberry $>$ Cranberry Beer $=$ Black Tea.

Most of the homogenates/extracts (mushroom was an exception) were able to inhibit $A$. naeslundii internalization.

The $P$. intermedia strain, in control tests, presented a low internalization capability or no internalization at all making it impossible to evaluate the effect of substances.

3.6. Inhibition of Host Cell Proinflammatory Cytokine Production Induced by the Target Organisms. The proinflammatory cytokine, IL-6, released by host cells in response to subgingival bacteria is considered to be a mediator of the inflammation accompanying gingivitis. Compounds able to prevent such cytokine production will, therefore, help to maintain the gingival tissues in a healthy state. The most effective bacterial inducer of IL- 6 from the Mono-Mac- 6 cells was determined. The cells were exposed to F. nucleatum cells, or P. intermedia cells, or LPS and the quantity of IL-6 released into the supernatant was assayed. The supernatant from $F$. nucleatum displayed the greatest IL-6 inducing activity and therefore was used in subsequent experiments. The results of chicory and mushroom homogenate are shown in Figure 1. Both Chicory and mushroom extracts inhibited the release of IL- 6 by the F. nucleatum supernatant. No other extract showed any activity.

3.7. Prevention of Adhesion to, and Induction of Detachment from, Hydroxyapatite (HA). All homogenates/extracts inhibited adhesion of the target bacteria to hydroxyapatite to some extent. The most active substance was shown to be Raspberry $=$ Cranberry $>$ Black Tea $>$ Mushroom $>$ Chicory $>$ Beer $>$ Green Tea.

Induction of detachment of caries-associated species ( $S$. mutans and L. casei) and S. sanguinis from HA beads by the Homogenates/extracts was determined. All tested substances induced a higher detachment from the hydroxyapatite beads in comparison to the respective controls.

The most effective material at inducing detachment was mushroom which detached $21 \%$ of S. mutans cells, $14 \%$ S. sanguinis cells, and $28 \%$ of $L$. casei cells. Overall ranked 
results were Mushroom $>$ Cranberry $>$ Chicory $>$ Green Tea $>$ Raspberry $>$ Beer.

3.8. Disruption of Signal Transduction. Some materials may affect the triggering of signal transduction suppression systems by bacteria and this may have an effect on colonization of teeth and the induction/progression of disease. The effect of $0.1 \%(\mathrm{v} / \mathrm{v})$ of the homogenates/extracts on $S$. mutans comDE gene expression was determined. All homogenates/extracts inhibited S. mutans comDE gene expression to some extent. The range of inhibition of gene expression was $87 \%$ to $21 \%$ of control. The overall ranked results were Mushroom > Beer > Chicory + Cranberry > Raspberry > Green Tea $>$ Black Tea.

3.9. Inhibition of Acid Production by Caries-Associated Species. Acid production was either unaffected by all the homogenates/extracts or increased.

\section{Most Appropriate Food and Beverages to Further Fractionate and Test}

The 9 assays were used to form a comprehensive set of tests aimed at easily assessing the anti-caries or anti-gingivitis nature of the homogenates/extracts. A large amount of data was generated and the collation and interpretation of this was challenging. In addition, aspects of intellectual property rights with some of the other foods and beverages (Cranberry, Black Tea, and Green tea) became apparent and this also therefore influenced the decision. Therefore based on all these aspects, raspberry, chicory, and mushroom extracts were taken forward for further fractionation and testing as potential anti-gingivitis agents, and mushroom extracts were taken forward for further fractionation and testing as a potential anti-caries agent.

Due to the labour intensive nature of performing all the assays with all the species, the utilization of the full set of assays for subsequent testing was reassessed. A decision was made to reduce both the number of assays and the number of species tested as appropriate for anti-caries or anti-gingivitis testing.

\section{Determination of Anticaries Activities of the HMM and LMM Fractions of Shiitake Mushroom}

The effects of the HMM and LMM fractions of the shiitake mushroom on organisms associated with caries and health in assays specifically relevant to this disease were carried out. The assays aimed to assess the ability of each test material to

(i) prevent adhesion of the target organisms to hydroxyapatite,

(ii) prevent biofilm formation by the target organisms,

(iii) elicit an antibacterial effect against the target organisms,

(iv) prevent coaggregation by the target organisms,

(v) disrupt preexisting biofilms of the target organisms.
The prevention of adhesion to hydroxyapatite assay showed that the LMM fraction of mushroom inhibited adherence of the target organisms to hydroxyapatite by c50\% while the HMM fraction only caused $15 \%$ inhibition. The LMM fraction of mushroom was able to inhibit biofilm formation of S. mutans by $99 \%$ and S. sanguinis by $87 \%$ while the HMM did not inhibit any formation with S. mutans and only $14 \%$ with S. sanguinis. The LMM fraction of mushroom showed a greater inhibition of bacterial growth (up to $1: 8$ dilution) against the target organisms than the HMM fraction which did not inhibit bacterial growth. The LMM fractions completely inhibited coaggregation of $F$. nucleatum plus $S$. mutans and F. nucleatum plus $N$. subflava while the HMM fractions did not show any inhibition with any pairing. The LMM disrupted L. casei and S. mutans biofilms by $60 \%$ and $58 \%$ (7\% and $30 \%$ dead cells), respectively, while the HMM disrupted L. casei and S. mutans biofilms by $45 \%$ and $31 \%$ ( $2 \%$ and $17 \%$ dead cells), respectively.

Based on the results from the assays of mushroom LMM and HMM fractions, the conclusion was that the LMM fraction was the most active and would be further fractionated.

\section{Determination of Antigingivitis and Anticaries Activities of the HMM and LMM Fractions of Mushroom, Chicory, and Raspberry}

The effects of the HMM and LMM fractions on organisms associated with gingivitis (A. naeslundii and P. intermedia) and caries (S. mutans, S. sanguinis, and L. casei) in assays specifically relevant to these diseases were carried out.

The assays aimed to assess the ability of each test material to

(i) prevent biofilm formation by target organism,

(ii) disrupt preexisting biofilms of the target organisms,

(iii) inhibit adhesion of organisms to epithelial cells,

(iv) inhibit adhesion to hydroxyapatite.

The LMM fractions of mushroom, raspberry, and chicory were more effective at preventing biofilm formation by the target gingivitis organisms (Chicory, 94\%; Mushroom, $97 \%$, and Raspberry, $100 \%$ inhibition) than the HMM fractions (Chicory, 7\%; Mushroom, 1\%, and Raspberry, 74\% inhibition). The LMM fractions of mushroom and raspberry, but not chicory, were able to inhibit biofilm formation by S. mutans (99\% and 32\%, resp.) Determination of the disruption of preexisting biofilms by the fractions is shown in Table 2. This shows that the LMM fractions of shiitake mushroom and chicory were most effective at disrupting biofilms of the target organisms (both caries associated and gingivitis associated) than the HMM fractions. In the case of raspberry, the HMM fraction was the most effective. The mushroom and raspberry also showed most antibacterial effect with up to $53 \%$ of cells killed (LMM Mushroom).

Both the LMM and HMM fractions of raspberry and chicory were able to inhibit adhesion of the target organisms 
TABLE 2: Percentage disruption of biofilms by HMM and LMM fractions of chicory, mushroom, and raspberry. Numbers in parenthesis are percentage of dead cells.

\begin{tabular}{|c|c|c|c|c|c|c|}
\hline \multirow[t]{3}{*}{ Target organism } & \multicolumn{6}{|c|}{ Homogenate/extract } \\
\hline & \multicolumn{2}{|c|}{ Chicory } & \multicolumn{2}{|c|}{ Mushroom } & \multicolumn{2}{|c|}{ Raspberry } \\
\hline & HMM & LMM & HMM & LMM & HMM & LMM \\
\hline S. mutans & $33.5(18.7)$ & $56.7(14.9)$ & $31.3(16.6)$ & $58.1(29.9)$ & nt & nt \\
\hline L. casei & $33.7(2.7)$ & $63.2(2.9)$ & $45.3(1.7)$ & $60.0(7.2)$ & $\mathrm{nt}$ & $\mathrm{nt}$ \\
\hline A. naeslundii & $4.3(1)$ & $40.4(8)$ & $47.9(38)$ & $51.1(39)$ & $40.3(31)$ & $37.5(30)$ \\
\hline P. intermedia & $8.2(2)$ & $28.7(7)$ & $11.6(9)$ & $63.1(53)$ & $58.1(29.9)$ & $33.9(24)$ \\
\hline
\end{tabular}

to epithelial cells. Neither the LMM nor HMM fractions of shiitake mushroom displayed inhibitory activity. The LMM fractions of mushroom, chicory, and raspberry had a greater inhibition of the growth of $A$. naeslundii and $P$. intermedia (up to $1: 16$ dilution for raspberry LMM) than the HMM fraction which inhibited to a max level of $1: 2$. Both the LMM and HMM fractions of mushroom, chicory, and raspberry were able to inhibit adherence of the target organisms to hydroxyapatite. LMM Chicory versus A. naeslundii and LMM Raspberry versus S. mutans are most effective (68\% and $62 \%$, resp.), while LMM Chicory versus $S$. mutans and LMM mushroom versus $A$. naeslundii are least effective (4\% and $14 \%$, resp.). It is interesting to note the difference in effectiveness of Chicory LMM versus different organisms.

Based on the results from the assays of mushroom, chicory, and raspberry LMM and HMM fractions, the conclusion was that the LMM fractions of mushroom and chicory were the most active and would be further fractionated. An additional issue was the fact that the most active fraction of raspberry also contained most of the fruit sugars.

Shiitake mushroom extract has previously been shown to have an inhibitory effect on a range of oral bacterial species $[44,45]$ and also on water-insoluble glucan formation by Streptococcus mutans and Streptococcus sobrinus [19]. Indeed, the same study also showed that in a rat model caries is reduced in rats fed with shiitake mushroom compared to controls. A number of different compounds from Shiitake, as aqueous extract, have been shown to have antimicrobial activity on food-borne pathogenic bacterial strains [45].

The antimicrobial nature of chicory has been evaluated against Agrobacterium sp, Erwinia carotovora, Pseudomonas fluorescens, and P. aeruginosa [46] and there is some evidence and folk literature supporting its use as an antimalarial. Apart from the Oligofructose being nonfermentable by $S$. mutans chicory has no known oral health benefits.

In conclusion, the homogenates and LMM fractions show promise as anti-caries and anti-gingivitis agents, and further testing and clinical trials will need to be performed to evaluate their true effectiveness in humans.

\section{Acknowledgment}

The research leading to these results has received funding from the European Union's Sixth Framework Programme (FP6) under the contract FOOD-CT-2006-036210 (project NUTRIDENT).

\section{References}

[1] J. Schrezenmeir and M. De Vrese, "Probiotics, prebiotics, and synbiotics-approaching a definition," American Journal of Clinical Nutrition, vol. 73, no. 2, 2001.

[2] J. T. LaMont, "The renaissance of probiotics and prebiotics," Gastroenterology, vol. 119, no. 2, p. 291, 2000.

[3] J. M. Hardie and R. A. Whiley, "Plaque microbiology of crown caries," in Dental Plaque Revisited, H. N. Newman and M. Wilson, Eds., pp. 283-294, Bioline, Cardiff, UK, 1999.

[4] H. F. Jenkinson, "Adherence and accumulation of oral streptococci," Trends in Microbiology, vol. 2, no. 6, pp. 209-212, 1994.

[5] W. J. Loesche, "Role of Streptococcus mutans in human dental decay," Microbiological Reviews, vol. 50, no. 4, pp. 353-380, 1986.

[6] C. J. Whittaker, C. M. Klier, and P. E. Kolenbrander, "Mechanisms of adhesion by oral bacteria," Annual Review of Microbiology, vol. 50, pp. 513-552, 1996.

[7] G. Hajishengallis and S. M. Michalek, "Current status of a mucosal vaccine against dental caries," Oral Microbiology and Immunology, vol. 14, no. 1, pp. 1-20, 1999.

[8] I. D. Mandel, "Caries prevention: current strategies, new directions," Journal of the American Dental Association, vol. 127, no. 10, pp. 1477-1488, 1996.

[9] J. Olsson, A. Carlén, and K. Holmberg, "Modulation of bacterial binding to salivary pellicle by treatment with hydrophilizing compounds," Archives of Oral Biology, vol. 35, no. 1, pp. S137-S140, 1990.

[10] M. W. Russell, G. Hajishengallis, N. K. Childers, and S. M. Michalek, "Secretory immunity in defense against cariogenic mutans streptococci," Caries Research, vol. 33, no. 1, pp. 4-15, 1999.

[11] R. Tarsi, R. A. A. Muzzarelli, C. A. Guzmàn, and C. Pruzzo, "Inhibition of Streptococcus mutans adsorption to hydroxyapatite by low-molecular-weight chitosans," Journal of Dental Research, vol. 76, no. 2, pp. 665-672, 1997.

[12] R. Tarsi, B. Corbin, C. Pruzzo, and R. A. A. Muzzarelli, "Effect of low-molecular-weight chitosans on the adhesive properties of oral streptococci," Oral Microbiology and Immunology, vol. 13, no. 4, pp. 217-224, 1998.

[13] T. Ooshima, T. Minami, W. Aono et al., "Oolong tea polyphenols inhibit experimental dental caries in SPF rats infected with mutans streptococci," Caries Research, vol. 27, no. 2, pp. 124-129, 1993.

[14] T. Ooshima, T. Minami, M. Matsumoto, T. Fujiwara, S. Sobue, and S. Hamada, "Comparison of the cariostatic effects between regimens to administer Oolong tea polyphenols in SPF rats," Caries Research, vol. 32, no. 1, pp. 75-80, 1998.

[15] T. Ooshima, T. Minami, W. Aono, Y. Tamura, and S. Hamada, "Reduction of dental plaque deposition in humans by oolong tea extract," Caries research, vol. 28, no. 3, pp. 146-149, 1994. 
[16] J. M. T. Hamilton-Miller, "Anti-cariogenic properties of tea (Camellia sinensis)," Journal of Medical Microbiology, vol. 50, no. 4, pp. 299-302, 2001.

[17] S. Otake, M. Makimura, T. Kuroki, Y. Nishihara, and M. Hirasawa, "Anticaries effects of polyphenolic compounds from Japanese green tea," Caries Research, vol. 25, no. 6, pp. 438-443, 1991.

[18] K. Ikeno, T. Ikeno, and C. Miyazawa, "Effects of propolis on dental caries in rats," Caries Research, vol. 25, no. 5, pp. $347-$ 351, 1991.

[19] N. Shouji, K. Takada, K. Fukushima, and M. Hirasawa, "Anticaries effect of a component from Shiitake (an Edible mushroom)," Caries Research, vol. 34, no. 1, pp. 94-98, 2000.

[20] A. Yanagida, T. Kanda, M. Tanabe, F. Matsudaira, and J. G. O. Cordeiro, "Inhibitory effects of apple polyphenols and related compounds on cariogenic factors of mutans streptococci," Journal of Agricultural and Food Chemistry, vol. 48, no. 11, pp. 5666-5671, 2000.

[21] F. N. Nogueira, D. N. Souza, and J. Nicolau, "In vitro approach to evaluate potential harmful effects of beer on teeth," Journal of Dentistry, vol. 28, no. 4, pp. 271-276, 2000.

[22] T. Ooshima, Y. Osaka, H. Sasaki, K. Osawa, H. Yasuda, and M. Matsumoto, "Cariostatic activity of cacao mass extract," Archives of Oral Biology, vol. 45, no. 9, pp. 805-808, 2000.

[23] K. Osawa, K. Miyazaki, S. Shimura, J. Okuda, M. Matsumoto, and T. Ooshima, "Identification of cariostatic substances in the cacao bean husk: their anti-glucosyltransferase and antibacterial activities," Journal of Dental Research, vol. 80, no. 11, pp. 2000-2004, 2001.

[24] M. Daglia, M. T. Cuzzoni, and C. Dacarro, "Antibacterial activity of coffee," Journal of Agricultural and Food Chemistry, vol. 42, no. 10, pp. 2270-2272, 1994.

[25] M. Daglia, M. T. Cuzzoni, and C. Dacarro, "Antibacterial activity of coffee: relationship between biological activity and chemical markers," Journal of Agricultural and Food Chemistry, vol. 42, no. 10, pp. 2273-2277, 1994.

[26] C. Dacarro et al., "Antibacterial activity of coffee against S. mutans," L'igiene Moderna, vol. 104, pp. 379-387, 1995.

[27] M. Daglia, R. Tarsi, A. Papetti et al., "Antiadhesive effect of green and roasted coffee on Streptococcus mutans' adhesive properties on saliva-coated hydroxyapatite beads," Journal of Agricultural and Food Chemistry, vol. 50, no. 5, pp. 1225-1229, 2002.

[28] H. Löe, "Physiology of the gingival pocket," Academy Review of the California Academy of Periodontology, vol. 13, no. 1, pp. 6-14, 1965.

[29] R. C. Page, “Gingivitis," Journal of Clinical Periodontology, vol. 13 , no. 5, pp. 345-359, 1986.

[30] P. J. Leggott, P. B. Robertson, D. L. Rothman, P. A. Murray, and R. A. Jacob, "The effect of controlled ascorbic acid depletion and supplementation on periodontal health," Journal of Periodontology, vol. 57, no. 8, pp. 480-485, 1986.

[31] M. E. Thomson and A. R. C. Pack, "Effects of extended systemic and topical folate supplementation on gingivitis of pregnancy," Journal of Clinical Periodontology, vol. 9, no. 3, pp. 275$280,1982$.

[32] S. Sakanaka, M. Aizawa, M. Kim, and T. Yamamoto, "Inhibitory effects of green tea polyphenols on growth and cellular adherence of an oral bacterium, Porphyromonas gingivalis," Bioscience, Biotechnology and Biochemistry, vol. 60, no. 5, pp. 745-749, 1996.

[33] E. I. Weiss, R. Lev-Dor, Y. Kashamn, J. Goldhar, N. Sharon, and I. Ofek, "Inhibiting interspecies coaggregation of plaque bacteria with a cranberry juice constituent," Journal of the
American Dental Association, vol. 129, no. 12, pp. 1719-1723, 1998.

[34] M. Tagashira, K. Uchiyama, T. Yoshimura, M. Shirota, and N. Uemitsu, "Inhibition by hop bract polyphenols of cellular adherence and water-insoluble glucan synthesis of mutans streptococci," Bioscience, Biotechnology and Biochemistry, vol. 61, no. 2, pp. 332-335, 1997.

[35] M. Matsumoto, T. Minami, H. Sasaki, S. Sobue, S. Hamada, and T. Ooshima, "Inhibitory effects of oolong tea extract on caries-inducing properties of mutans Streptococci," Caries Research, vol. 33, no. 6, pp. 441-445, 1999.

[36] M. Daglia, A. Papetti, D. Mascherpa et al., "Plant and fungal food components with potential activity on the development of microbial oral diseases," Journal of Biomedicine and Biotechnology, vol. 2011, Article ID 274578, 9 pages, 2011.

[37] J. O. Cisar, P. E. Kolenbrander, and F. C. McIntire, "Specificity of coaggregation reactions between human oral streptococci and strains of Actinomyces viscosus or Actinomyces naeslundii," Infection and Immunity, vol. 24, no. 3, pp. 742-752, 1979.

[38] G. Bryce, D. O’Donnell, D. Ready, Y. L. Ng, J. Pratten, and K. Gulabivala, "Contemporary root canal irrigants are able to disrupt and eradicate single- and dual-species biofilms," Journal of Endodontics, vol. 35, no. 9, pp. 1243-1248, 2009.

[39] A. Tam, M. Shemesh, U. Wormser, A. Sintov, and D. Steinberg, "Effect of different iodine formulations on the expression and activity of Streptococcus mutans glucosyltransferase and fructosyltransferase in biofilm and planktonic environments," Journal of Antimicrobial Chemotherapy, vol. 57, no. 5, pp. 865$871,2006$.

[40] G. Wang, C. Barton, and F. G. Rodgers, "Bacterial DNA decontamination for reverse transcription polymerase chain reaction (RT-PCR)," Journal of Microbiological Methods, vol. 51, no. 1, pp. 119-121, 2002.

[41] M. Shemesh, A. Tam, M. Feldman, and D. Steinberg, "Differential expression profiles of Streptococcus mutans $\mathrm{ftf}$, gtf and vicR genes in the presence of dietary carbohydrates at early and late exponential growth phases," Carbohydrate Research, vol. 341, no. 12, pp. 2090-2097, 2006.

[42] J. J. M. Damen, M. J. Buijs, and J. M. Ten Cate, "Acidogenicity of buccal plaque after a single rinse with amine fluoridestannous fluoride mouthrinse solution," Caries Research, vol. 36, no. 1, pp. 53-57, 2002.

[43] S. A. Syed and W. J. Loesche, "Survival of human dental plaque flora in various transport media," Applied microbiology, vol. 24, no. 4, pp. 638-644, 1972.

[44] M. Hirasawa, N. Shouji, T. Neta, K. Fukushima, and K. Takada, "Three kinds of antibacterial substances from Lentinus edodes (Berk.) Sing. (Shiitake, an edible mushroom)," International Journal of Antimicrobial Agents, vol. 11, no. 2, pp. 151-157, 1999.

[45] M. E. Venturini, C. S. Rivera, C. Gonzalez, and D. Blanco, "Antimicrobial activity of extracts of edible wild and cultivated mushrooms against foodborne bacterial strains," Journal of Food Protection, vol. 71, no. 8, pp. 1701-1706, 2008.

[46] J. Petrovic, A. Stanojkovic, L. Comic, and S. Curcic, "Antibacterial activity of Cichorium intybus," Fitoterapia, vol. 75, no. 7-8, pp. 737-739, 2004. 

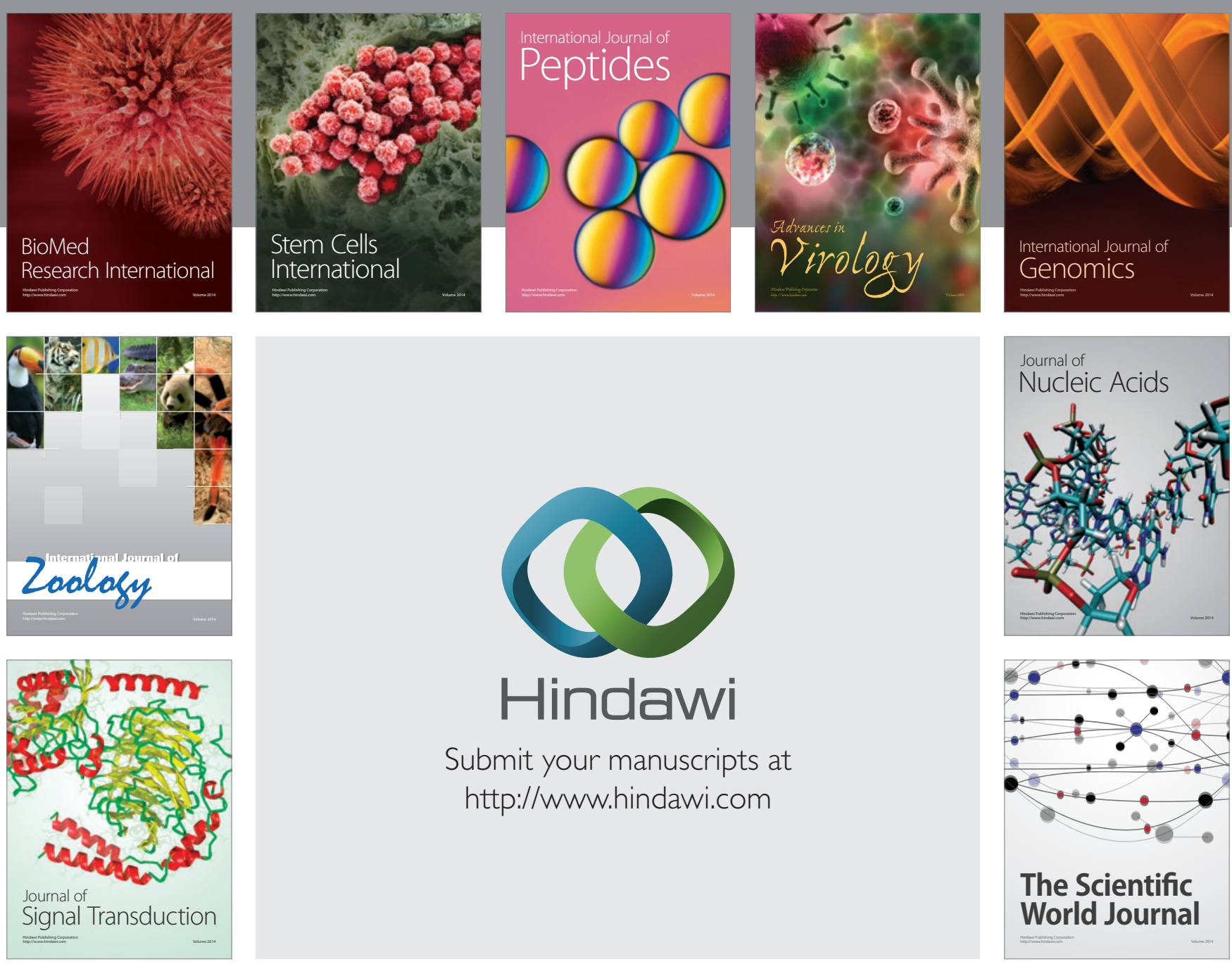

Submit your manuscripts at

http://www.hindawi.com
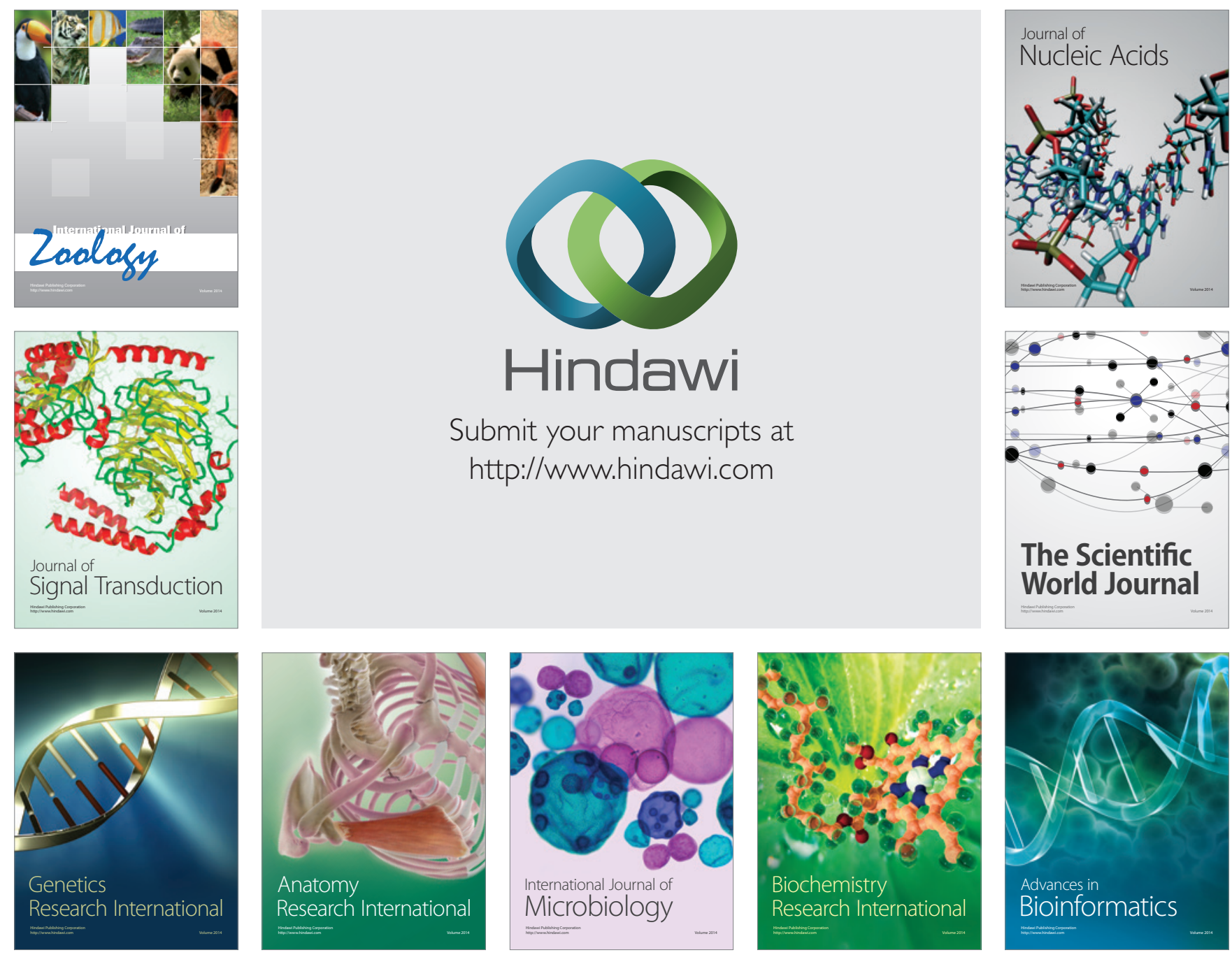

The Scientific World Journal
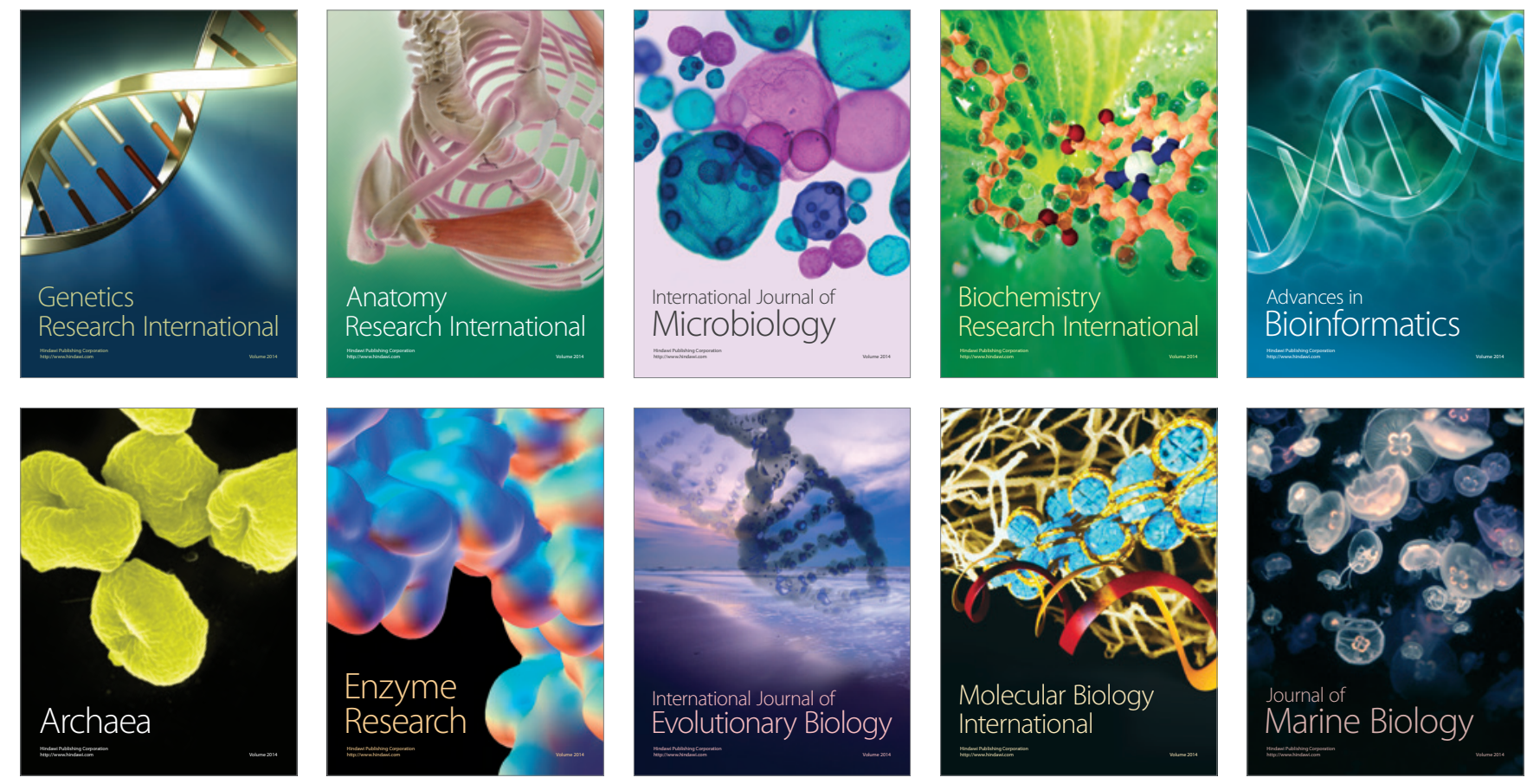